\title{
Potential of apple varieties of the Ural-Siberian and Far Eastern group for use in breeding for winter hardiness
}

\author{
Natalya Saveleva ${ }^{1,2, *}$, Andrey Yushkov ${ }^{1,2}$, Alexander Zemisov ${ }^{1}$, Nadezhda Borzykh $^{1}$, and \\ Vladislav Chivilev ${ }^{1}$ \\ ${ }^{1}$ Federal State Scientific Institution «I. V. Michurin Federal Scientific Center», 393770 Michurinsk, \\ Russian Federation \\ ${ }^{2}$ Federal State Budgetary Educational Institution of Higher Education "Michurinsk State Agrarian \\ University", 393760 Michurinsk, Russian Federation
}

\begin{abstract}
The gene pool of apple varieties of the Ural-Siberian and Far Eastern group has a valuable genetic potential especially in breeding for winter hardiness. Today, apple breeding research focused on winter hardiness using that varieties is limited. Using in hybridization gene pools created in harsh conditions of Siberia and the Far East will allow promoting the spread of apple culture to the north, which is mainly limited by frost resistance. Assessment of frost damage level of tissues and kidneys of apple shoots by $-40^{\circ} \mathrm{C}$ temperature decrease was the principal goal of the work. According the national food and nutrition security policy, share of fruit production in the northern regions must be increased. In that case, ongoing scientific research has the defining value for these purposes. Different apple tree genotypes responses to low temperatures is highly individual and depends both of the degree or strength of frost and of the sensitivity of the plant itself. This complex interrelationship determinates the winter hardiness level under negative environmental conditions. 30 varieties of apple tree of the Ural-Siberian and Far Eastern groups were selected for study of frost resistance. Genotypes have a sufficient "margin of safety" for resistance to cause by frost damages.
\end{abstract}

\section{Introduction}

Apple tree frost resistance level is particularly relevant in the face of global climate change. On the one hand, plants can avoid low winter temperatures for a long time during their life. However, it doesn't exclude the occurrence of hard frosts in some years, as well as repeated for several years [1]. During the period of forced dormancy, when the impact of low air temperature combined with susceptibility to frost, trees become particularly vulnerable $[2,3]$.

The winter resistance of fruit trees, including apple trees, is closely related to the state of cell sap. Water content in the tissues of plants may exists in the different physical states from free to hard-bound, which increase the frost tolerance. Therefore, passaging the

\footnotetext{
${ }^{*}$ Corresponding author: cglm@rambler.ru
} 
quenching phase, the rate of air temperature decrease, and the intracellular osmotic pressure increase are crucial in ensuring of frost resistance [4,5].

Against the background of winter temperatures increasing, the introduction of southern varieties to more northern horticulture zones has become widespread. Those varieties has a low level of winter resistance, since they are selected in warm climate areas, where this feature is not decisive [6]. One frosty winter can negate many years of fruit production efforts and cause significant economic losses $[7,8]$.

Maximum air temperature decrease is a key factor limiting the cultivation and distribution of apple trees in the mid horticulture zone. More than $98 \%$ of all apple orchards winter damages have been caused by extremely low temperatures [9]. However, those damages can only be noticeable from the beginning of the growing season. In this case, exploring of frost resistance in the field is rather complicated [10]. Represented research work was conducted by a laboratory methods closely correlates with field observations. Malus domestica frost resistance lower limit is currently about of $42-44^{\circ} \mathrm{C}$ below zero, but although genotypes with an even more significant "resistance margin", withstanding temperatures up to- $49^{\circ} \mathrm{C}$ have been created $[11,12,13,14,15]$.

\section{Materials and methods of research}

The research was carried out in 2017-2020 based on the Selection and Genetic Center of Federal State Scientific Institution «I. V. Michurin Federal Scientific Center» in Michurinsk, Tambov region. The object of research was the maximum frost resistance of studied apple trees genotypes (2nd component of winter hardiness). 30 varieties of UralSiberian and Far Eastern breeding were selected from the genetic collection of the Institute for the experiment. As a control was used the winter grade Bogatyr, area-based in Central Black Earth Region. Tree planting scheme was $6 \times 3 \mathrm{~m}$, rootstock 54-118 was used. The age of the plantings is 12 years.

The study of potential of the frost resistance was carried out according to the standard methodology [16]. Annual shoots of each variety in the amount of 5 pieces in three-fold repetition were harvested as soon as negative air temperature was stable. Imitation of the winter damaging factors (maximum frost resistance) was conducted using the following test mode: quenching at $-5-10^{\circ} \mathrm{C}$ within 10 days, followed by freezing at $-40^{\circ} \mathrm{C}$ within 18 hours. The climate chamber of heat and cold SM-60/100-250 TH was used. Thawing was carried out for 24 hours at a rate of temperature increase of $3.5^{\circ} \mathrm{C}$ per hour. Then the annual shoots were placed for growing in vessels with water for 14-20 days. Microsoft Office Excel 2010 was used for processing and analysis of the results.

\section{Results and discussion}

Apple varieties of the Ural-Siberian and Far Eastern breeding group, due to genotypic features and the physiological influence of hardening, showed frost resistance and survival level higher or the same as Bogatyr control variety (Table 1). It was found that exposed to low temperatures tissues and kidneys have different susceptibility to this stressor. 
Table 1. Sensitivity to low temperature $\left(-40^{\circ} \mathrm{C}\right)$ of tissues and vegetative organs of apple varieties of the Ural-Siberian and Far Eastern group

\begin{tabular}{|c|c|c|c|c|c|c|}
\hline \multirow[b]{2}{*}{ № } & \multirow[b]{2}{*}{ Variety } & \multicolumn{5}{|c|}{ Damage level, point } \\
\hline & & bark & cambium & wood & $\begin{array}{c}\text { average by } \\
\text { tissues, } \\
\sqrt{x}+1\end{array}$ & kidneys \\
\hline 1 & Altayskoye bagryanoye & 0 & 0 & 0 & 1,0 & 0 \\
\hline 2 & Amurskoye urozhaynoye & 0 & 0 & 0 & 1,0 & 0 \\
\hline 3 & Aborigen & 0 & 0 & 0 & 1,0 & 0 \\
\hline 4 & Altayskoye naryadnoye & 0 & 0 & 0 & 1,0 & 0 \\
\hline 5 & Alyye parusa & 0 & 0 & 0 & 1,0 & 0 \\
\hline 6 & Baganenok & 0 & 0 & 0 & 1,0 & 0 \\
\hline 7 & Grushovka vostochnaya & 0 & 0 & 0 & 1,0 & 0 \\
\hline 8 & Krasnaya grozd & 0 & 0 & 0 & 1,0 & 0 \\
\hline 9 & Naliv amurskiy & 0 & 0 & 0 & 1,0 & 0 \\
\hline 10 & Pavlusha & 0 & 0 & 0 & 1,0 & 0 \\
\hline 11 & Stepnoe & 0 & 0 & 0 & 1,0 & 0 \\
\hline 12 & Slava Primorya & 0 & 0 & 0 & 1,0 & 0 \\
\hline 13 & Tonkonozhka & 0 & 0 & 0 & 1,0 & 0 \\
\hline 14 & Pepinchik krasnoyarskiy & 0 & 0 & 0,2 & 1,1 & 0 \\
\hline 15 & Dalnevostochnaya rannyaya & 0 & 0 & 0,3 & 1,2 & 0 \\
\hline 16 & Uralskoye nalivnoye & 0 & 0 & 0,4 & 1,2 & 0 \\
\hline 17 & Kitayka saninskaya & 0 & 0 & 0,5 & 1,2 & 0 \\
\hline 18 & Kitayka zolotaya rannyaya & 0 & 0 & 0,5 & 1,2 & 0 \\
\hline 19 & Bashkirskiy krasavets & 0 & 0 & 0,6 & 1,3 & 0 \\
\hline 20 & Lyubimets Nadezhdy & 0 & 0 & 0,7 & 1,3 & 0,5 \\
\hline 21 & Krasa Sverdlovska & 0 & 0 & 0,8 & 1,3 & 0 \\
\hline 22 & Bashkirskiy izumrud & 0 & 0 & 0,9 & 1,4 & 0 \\
\hline 23 & Bagration & 0 & 0 & 0,9 & 1,4 & 0 \\
\hline 24 & Zelenka sochnaya & 0 & 0 & 1,0 & 1,4 & 0 \\
\hline 25 & Primorskoye & 0 & 0 & 1,1 & 1,5 & 0 \\
\hline 26 & Sibirskaya sladkaya & 0 & 0 & 1,3 & 1,5 & 0 \\
\hline 27 & Birskaya grushovka & 0 & 0 & 1,5 & 1,6 & 0 \\
\hline 28 & Syurpriz Altaya & 0 & 0 & 1,5 & 1,6 & 0 \\
\hline 29 & Altayskoye purpurovoye & 0 & 0 & 1,7 & 1,6 & 0 \\
\hline 30 & Zorenka & 0 & 0 & 2,0 & 1,7 & 0 \\
\hline 31 & Bogatyr' (c) & 0 & 0 & 1,9 & 1,7 & 1,2 \\
\hline & $\mathrm{LSD}_{05}$ & & & & 0,17 & \\
\hline
\end{tabular}

More than $43 \%$ of the studied varieties showed no signs of frost damage of the tissues and buds of annual shoots. It allows concluding about significant acclimatization in Central Black Earth Region of such genotypes as Altayskoye bagryanoye, Amurskoye urozhaynoye, Aborigen, Altayskoye naryadnoye, Alyye parusa, Baganenok, Grushovka vostochnaya, Krasnaya grozd, Naliv amurskiy, Pavlusha, Stepnoe, Slava Primorya, Tonkonozhka etc.

During the research period, all studied varieties showed stable results of maximum frost resistance level, which doesn't significantly change over the years. Wood, as the most sensitive tissue to the lowest possible temperature, was characterized by heterogeneity of the analyzed parameters.

$33 \%$ of the studied varieties such as Pepinchik krasnoyarskiy, Dalnevostochnaya rannyaya, Uralskoye nalivnoye, Kitayka saninskaya, Kitayka zolotaya rannyaya, Bashkirskiy krasavets, Krasa Sverdlovska, Bashkirskiy izumrud, Bagration showed wood damage level up to 1 point. Lyubimets Nadezhdy variety stands out in this group and had a freezing damage of the kidneys at the level of 0.5 points along with wood freezing damage.

$23 \%$ of the studied genotypes had a higher level of wood sensitivity to temperature decrease up to $-40^{\circ} \mathrm{C}$. Sibirskaya sladkaya, Birskaya grushovka, Syurpriz Altaya, 
Altayskoye purpurovoye and Zorenka varities had damage level not exceeding 2 points. Such damage level is reversible unless there are no new stressors.

\section{Conclusions}

As a result of the research all tested genotypes didn't show any manifestations of lethal stress caused by hypothermia was revealed. The temperature lowering up to $-40^{\circ} \mathrm{C}$ didn't induce significant damage for the vegetative organs of varieties of the Ural-Siberian and Far Eastern group. The obtained information have a high predictive value for further monitoring of stress resistance. This is especially important in changing temperature conditions of unstable climate to develop the strategies driving frost resistance of the creating genotypes.

\section{References}

1. E. D. Cittadini, N. de Ridder, P.L. Peri, H. van Keulen, Agric. For. Meteorol., 141, 235 (2006)

2. W. Larcher, C. Kainmueller, J. Wagner, Flora, 205, 3 (2010)

3. C. Kollas, C. Koerner, C.F. Randin, J. Biogeogr., 41, 773 (2014)

4. J. Wolfe, G. Bryant, Int. J. Refrig., 24, 438 (2001)

5. M. Pramsohler, G. Neuner, Tree Physiol., 33, 807 (2013)

6. B. Fady, F. Ducci, N. Aleta, J. Becquey, R.D. Vazquez, F.F. Lopez et al., New For., 25, 211 (2003)

7. J.A. Attaway, A History of Florida Citrus Freezes (1997)

8. A.S. Zemisov, N.N. Saveleva, A.N. Yushkov, V.V. Chivilev, N.V. Borzykh, Pomiculture and small fruits culture in Russia, 63(1), 70 (2020)

9. V.V. Kichina, Principles of improvement of horticultural plants (in Russian), 528 (2011)

10. G. Charrier, H. Cochard, T. Améglio, Tree Physiol., 33, 891 (2013)

11. N.N. Saveleva, Biological and genetic peculiarities of apple and breeding of immune to scab and columnar varieties, 280 (2016)

12. A. Lenz, G. Hoch, Y. Vitasse, C. Koerner, New Phytol., 200, 1166 (2013)

13. N.I. Savelev, Genetic basis of apple breeding, 304 (1998)

14. A.N. Yushkov, Adaptive potential and breeding of fruit plants for resistance to abiotic stressors. PhD, 382 (2017)

15. N.G. Krasova, A.M. Galasheva, Z.E. Ozherelieva, L.V. Golyshkina, M.A. Makarkina, Agricultural biology, 49(1), 42 (2014)

16. M.M. Tyurina, G.A. Gogoleva, Accelerated assessment of winter hardiness of fruit and berry plants. Methodological recommendations, 38 (1978) 